\title{
EXPLAINING THE UNDECLARED ECONOMY IN BULGARIA: AN INSTITUTIONAL ASYMMETRY PERSPECTIVE
}

Colin C Williams, Josip Franic and Rositsa Dzhekova *

\begin{abstract}
This paper proposes a way of explaining the undeclared economy that represents participation in undeclared work as a violation of the social contract between the state and its citizens, and as arising when the informal institutions comprising the norms, values and beliefs of citizens (civic morality) do not align with the codified laws and regulations of a society's formal institutions (state morality). Drawing upon evidence from 1,018 face-to-face interviews conducted in Bulgaria during 2013, the finding is that the greater is the asymmetry between formal and informal institutions (i.e., citizens' civic morality and state morality), the greater is the likelihood of participation in the undeclared economy, and vice versa. The outcome is that tackling the undeclared economy requires a focus upon reducing this lack of alignment of formal and informal institutions. How this can be achieved in Bulgaria in particular and South-East Europe and beyond more generally, is then discussed.
\end{abstract}

JEL codes: $H 26, J 46,017$

Keywords: informal sector; shadow economy; tax morale; institutional theory; Bulgaria, South-East Europe.

\section{Acknowledgements}

This paper is an output of the European Commission's Framework 7 Industry-Academia Partnerships Programme (IAPP) grant no. 611259 entitled "Out of the shadows: developing capacities and capabilities for tackling undeclared work in Bulgaria, Croatia and FYR Macedonia" (GREY). The usual disclaimers apply.

\section{INTRODUCTION}

In recent years, a burgeoning literature has revealed the size of the undeclared economy in SouthEastern Europe and its crucial role in providing citizens with a means of getting-by (Baric and Williams 2013, Dzhekova and Williams 2014, Dzhekova et al. 2014, Franic and Williams 2014, Gaspareniene et al. 2014, Hudson et al., 2012, Remeikiene et al. 2014, Schneider 2013; Williams 2012). With around a quarter of national income in South-East Europe not declared to the authorities and a similar share of total employment in the undeclared economy (Schneider and Williams 2013), tackling participation in the

\section{* Colin C Williams}

Professor of Public Policy

Management School, University of Sheffield, UK C.C.Williams@sheffield.ac.uk

\section{Josip Franic}

Marie Curie Research Fellow

Management School, University of Sheffield, UK jfranic1@sheffield.ac.uk

\section{Rositsa Dzhekova}

Marie Curie Research Fellow

Management School, University of Sheffield, UK rndzhekova1@sheffield.ac.uk 
undeclared economy is not some relatively minor issue of limited importance. This sphere not only leads to governments losing considerable public revenue that could otherwise pay for wider social cohesion and social protection, but also results in poorer quality working conditions and unfair competition for legitimate businesses. Indeed, unless addressed, pressure occurs on legitimate businesses in South-East Europe to themselves flout the formal regulations, resulting in a vicious and ongoing levelling down of working conditions (Andrews et al. 2011, ILO 2014).

Participation in the undeclared economy in SouthEast Europe and beyond has been so far explained largely in terms of country-level structural conditions such as the level of economic development and the lack of modern state bureaucracies, public sector corruption and high taxes, or inadequate levels of social protection and intervention in work and welfare by the state (see Williams 2013). These country-level structural explanations of the undeclared economy however, are unable to explain why some citizens in a country participate in the undeclared economy and others do not. That is to say, they fail to take agency into account in their explanations.

The aim of this paper therefore, is to advance a way of explaining the undeclared economy in South-East Europe that takes agency into account. Drawing upon institutional theory (Baumol and Blinder 2008, Helmke and Levitsky 2004, North 1990), the undeclared economy is here explained as a violation of the social contract between the state and its citizens, and as arising when there is a lack of alignment of the codified laws and regulations of a society's formal institutions with the norms, beliefs and values of its citizens (i.e., informal institutions). The proposition is that the greater is this lack of alignment between the formal and informal institutions, the greater is the likelihood of participation in the undeclared economy, and vice versa. If valid, this has consequences for how the undeclared economy is tackled. Reducing this institutional asymmetry necessitates a very different policy approach to the approach currently adopted in South-East Europe and beyond.

To evaluate this way of explaining the undeclared economy, therefore, section 2 provides a brief review of the shortcomings of previous explanations of the undeclared economy and proposes an explanation grounded in institutional theory to overcome these shortcomings. To evaluate this institutional asymmetry thesis, section 3 then introduces the methodology and data used, namely a stepwise Tobit regression analysis of the association between participation in the undeclared economy and the degree of institutional asymmetry using data from 1,018 face-to-face interviews conducted in Bulgaria during 2013. Section 4 then presents the findings followed in section 5 by a discussion of the theoretical and policy implications, and in section 6 some conclusions along with the limitations of this study and future research required.

At the outset however, the undeclared economy needs to be defined. For Castells and Portes (1989: $15)$, such endeavour is 'a specific form of income generating production... unregulated by the institutions of society in a legal and social environment in which similar activities are regulated'. Although this defines the undeclared economy through the lens of both the formal ('legal') and informal ('social') institutions in a society, this definition fails to recognise firstly, that the undeclared economy, even if unregulated by formal institutions, is regulated by the rules of informal institutions and secondly, that such work can be considered 'legitimate' from the stance of informal institutions even if 'illegal' from the viewpoint of formal institutions (Siqueira et al. 2014, Webb et al. 2009). In consequence, and reflecting the consensus in the literature, we here define the undeclared economy as socially legitimate paid work that is legal in all respects other than it is not declared to the authorities for tax, social security or labour law purposes (European Commission 2007, OECD 2012, Williams 2014a,b). If it is illegal in other respects and also socially illegitimate, it is not part of the undeclared economy but rather part of the criminal economy (e.g., forced labour) which is both illegal from the viewpoint of formal institutions and illegitimate from the viewpoint of informal institutions.

\section{Explaining the undeclared economy in South- East Europe}

Since the turn of the millennium, there has been growing recognition that the undeclared economy is a significant component of South-East European economies. As Schneider (2013) for example has estimated, the undeclared economy in 2013 was the equivalent of 31.2 per cent of GDP in Bulgaria, 28.4 per cent in Croatia, 28.4 per cent in Romania, 26.5 per cent in Turkey, 25.2 per cent in Cyprus, 23.6 per cent in Greece and 23.1 per cent in Slovenia. Meanwhile, Williams (2014a) estimates that the share of employment which is in the undeclared economy in 2013 as 22.7 per cent in Croatia, 19.6 per cent in Slovenia, 15.7 per cent in Bulgaria, 15.0 per cent in Greece, 14.6 per cent in Romania and 6.3 per cent in Cyprus.

Undeclared economies of this magnitude have significant implications for governments and societies. As Table 1 reveals, and based on 2009 figures, the average size of the undeclared economy in the five 
Table 1 Tax revenue lost as a result of the undeclared economy, five South-East European countries

\begin{tabular}{|c|c|c|c|c|c|c|c|c|}
\hline Country & $\begin{array}{l}\text { GDP } \\
2009\end{array}$ & $\begin{array}{l}\text { Size of un- } \\
\text { declared } \\
\text { economy } \\
2009\end{array}$ & $\begin{array}{c}\text { Tax } \\
\text { burden } \\
2009\end{array}$ & $\begin{array}{c}\text { Tax revenue } \\
\text { lost as a result } \\
\text { of undeclared } \\
\text { economy }\end{array}$ & $\begin{array}{l}\text { Gov't spend- } \\
\text { ing as } \% \text { of } \\
\text { GDP }\end{array}$ & $\begin{array}{l}\text { Tax lost } \\
\text { as a \% } \\
\text { of gov't } \\
\text { spending }\end{array}$ & $\begin{array}{l}\text { Health care } \\
\text { spending } \\
\text { as } \% \text { of } \\
\text { GDP }\end{array}$ & $\begin{array}{c}\text { Tax lost } \\
\text { as \% of } \\
\text { healthcare } \\
\text { spending }\end{array}$ \\
\hline & Euro'm & $\%$ & $\%$ & Euro'm & $\%$ & $\%$ & $\%$ & $\%$ \\
\hline Bulgaria & 36,000 & 35.3 & 28.9 & 3,673 & 37.3 & 27.4 & 7.4 & 137.9 \\
\hline Cyprus & 17,000 & 28.0 & 35.1 & 1,671 & 42.6 & 23.1 & 6.0 & 163.8 \\
\hline Greece & 230,000 & 27.5 & 30.3 & 19,165 & 46.8 & 17.8 & 7.4 & 112.6 \\
\hline Romania & 122,000 & 32.6 & 27.0 & 10,738 & 37.6 & 23.4 & 5.4 & 163.0 \\
\hline Slovenia & 36,000 & 26.2 & 37.6 & 3,546 & 44.3 & 22.2 & 9.1 & 108.3 \\
\hline $\begin{array}{l}\text { Total or } \\
\text { unweighted } \\
\text { average }\end{array}$ & 441,000 & 29.9 & 31.8 & 38,793 & & 22.8 & & 137.1 \\
\hline
\end{tabular}

Source: derived from Murphy (2012)

South-East European countries analysed was 29.9 per cent of GDP and on average, 22.8 per cent of the total tax revenue was lost in these countries. This equates to 137 per cent of current health care spending. Put another way, spending on health care in these countries could more than double if those operating in the undeclared economy paid their taxes.

Examining the variations in the size of the undeclared economy across South-East Europe, and as shown above, Bulgaria is often identified as having one of the largest undeclared economies. Indeed, indirect measurement methods using proxy indicators to measure its prevalence find the undeclared economy to be on average the equivalent of around one-third of total GDP (Bogdanov and Stanchev 2010, Elgin and Öztunali 2012, Ministry of Finance 2011, Nenovski and Hristov 2000, Schneider 2013). Direct surveys of the size of the undeclared economy in Bulgaria, meanwhile, find that on average some one-fifth of employment is in the undeclared economy (BICA 2012, CSD 2011, 2013, Loukanova and Bezlov 2007, Peracchi et al 2007, Perotti and Sanchez Puerta 2009, Stanchev 2005, Williams 2014a).

There have also been studies of the character of the Bulgarian undeclared economy. Firstly, these reveal firm-level variations in the prevalence of the undeclared economy with greater involvement amongst small and medium-sized businesses (BICA 2011a, CSD 2011, 2012, Dzhekova and Williams 2014, European Commission 2007). Secondly, they reveal sectorial variations with the undeclared economy more prevalent in construction, retail, tourism, hotels and restaurants, real estate, garments, food processing and the agricultural sectors as well as some services. Overall, it is labour-intensive, low technology sectors identified to be the sectors with the highest prevalence of the undeclared economy (BICA 2011a, CSD 2011, 2012, General Labour Inspectorate 2013). Thirdly, studies have been conducted of the nature of undeclared work, showing that most is wholly or partially undeclared waged employment (50 per cent of all undeclared work) and that under-reporting salaries is more common than working without a contract, with some one-fifth of the formally employed receiving an additional undeclared 'envelope' wage from their employer (Dzhekova and Williams 2014). Fourthly, the socio-demographic and socio-economic characteristics of those operating in the undeclared economy have been analysed. This reveals that men are more likely to work undeclared than women, as are those aged 4554 years old, the unemployed and those from small/ middle-sized towns and rural areas (Dzhekova and Williams 2014).

Despite these variations within Bulgaria across firm-types, sectors, population groups and places, explanations for the undeclared economy have largely focused upon country-level variables. As Williams (2014a) summarises, three major competing theoretical explanations exist. Firstly, 'modernisation' theory explains the undeclared economy in terms of the lack of economic development and modernisation of state bureaucracies (Geertz 1969, ILO 2013, Lewis 1959), secondly, 'neo-liberal' theory explains the undeclared economy as resulting from high taxes and too much state interference in the workings of the free market (De Soto 1989, 2001, Nwabuzor 2005) and third and finally, 'political economy' theory explains this sphere as resulting from inadequate state intervention and a lack of safeguards for workers (Castells and Portes 1989, Dau and Cuervo-Cazurra 2014, ILO 2014, Meagher 2010, Slavnic 2010). The problem with all these theories however, is that they do not explain 
why some within a country participate in the undeclared economy and others do not. The reason this is important is because although earlier studies assumed that participation in undeclared work was necessity-driven (Castells and Portes 1989, Gallin 2001), more recent studies reveal that for the majority, participation in the undeclared economy is more a matter of choice, rather than due to a lack of choice (Maloney 2004, Round et al. 2008, Williams et al 2013).

Here therefore, a new way of explaining the undeclared economy which takes agency into account is proposed. To do this, we draw upon institutional theory which views institutions as setting the rules of the game by prescribing the norms regarding the acceptability of activities (Baumol and Blinder 2008, Denzau and North 1994, Dolenec 2013, Gërxhani 2004a,b, Mathias et al. 2014, North 1990, Podrug 2011). All societies have codified laws and regulations (i.e., formal institutions) that set the legal rules of the game (prescribing 'state morality'). They also have informal institutions which are norms, values and beliefs of the citizens; the 'socially shared rules, usually unwritten, that are created, communicated and enforced outside of officially sanctioned channels' (Helmke and Levitsky 2004: 727). These prescribe 'civic morality'.

When symmetry exists between the formal and informal institutions, the undeclared economy will be largely absent since citizens will seek to adhere to the legal rules of the game. The only reason informality will take place is because citizens unintentionally do so, such as due to the rules being not simple enough to understand or to complex too fulfil. However, if there is asymmetry between a society's formal institutions and its informal institutions, such as due to a lack of trust in government, the undeclared economy will be larger. Indeed, this is widely recognised in Bulgaria. Surveys have repeatedly pointed to a lack of trust in government due to for example public sector corruption and an inefficient judiciary as key reasons for the existence of undeclared work (European Commission 2012a, Goev 2009, CSD 2011). Indeed, the World Economic Forum's Global Competitiveness Report ranks Bulgaria 112 out of 148 countries in terms of the quality of its institutions in 2014, with particularly low scores given to public trust in politicians (1.9 out of 7), favouritism in decisions of government officials (2.1 out of 7) and judicial independence (2.3) (WEF 2014). The result is that national surveys show that undeclared work, although illegal from the viewpoint of formal institutions, enjoys high levels of social legitimacy in Bulgaria (BICA 2011a, 2011b, 2012a, CSD 2011, 2013, Chavdarova 2013). Here, therefore, and to test this new institutional theory that views the undeclared economy as arising from the asymmetry between state morality and civic morality, the following proposition can be evaluated:

Institutional asymmetry thesis: the greater is the asymmetry between formal and informal institutions, the greater is the propensity to participate in the undeclared economy.

\section{DATA AND METHODOLOGY}

To evaluate this institutional asymmetry thesis, we here examine Bulgaria which as shown above has one of the largest undeclared economies in South-East Europe, and therefore should possess a high level of institutional asymmetry. This is here investigated by reporting data from special Eurobarometer survey no. 402, which involved 1,018 face-to-face interviews conducted in 2013. A multi-stage random (probability) sampling methodology was used to ensure that on the issues of gender, age, region and locality size, both the Bulgarian national level sample as well as each level of the sample, was representative in proportion to its population size.

In the face-to-face interviews, participants were firstly asked questions regarding their attitudes regarding the acceptability of various types of undeclared work, followed by questions on whether they had purchased from the undeclared economy and finally, whether they had participated in the undeclared economy in the prior 12 months. Here, we focus upon firstly, their attitudes regarding the acceptability of working in the undeclared economy, which measures the degree of institutional asymmetry, and secondly, whether they had participated in the undeclared economy.

To measure the level of institutional symmetry, participants were asked to rate the acceptability of five types of undeclared work using a 10-point Likert scale ( 1 equals absolutely unacceptable and 10 equals absolutely acceptable). These five types of undeclared work were: an individual is hired by a household for work and he/she does not declare the payment received to the tax or social security authorities even though it should be declared; a firm is hired by a household for work and it does not declare the payment received to the tax or social security authorities; a firm is hired by another firm for work and it does not declare its activities to the tax or social security authorities; a firm hires an individual and all or a part of the wages paid to him/her are not officially declared; and someone evades taxes by not declaring or only partially declaring their income.

Previous studies examining the acceptability of the undeclared economy have tended to use a single-item 
measurement by constructing an aggregate index from such questions (Daude, Gutiérrez and Melguizo 2013, Frey and Torgler 2007, Ristovska, MojsoskaBlazevski and Nikolov 2012, Torgler 2004, Williams and Martinez 2014a,b). However, and as Table 2 reveals, although an examination of the pairwise correlations indicates substantial cohesion among the five observed variables, with a high Cronbach's alpha value when all five variables are in the model $(a=0.89)$, it also reveals that the first type of undeclared work (i.e., undeclared work by an individual for a private household) is not strongly correlated with the other four. There is an increase in both inter-item correlation and Cronbach's alpha when this first variable is excluded, which is not the case with the remaining four variables. Given the higher level of social legitimacy of undeclared work by individuals for households compared with other types of undeclared work in Bulgaria, this suggests that this type of undeclared work should be analysed separately from the other types of undeclared work.

Given that this first type of undeclared work needs to be considered separately in the stepwise Tobit regression analysis, Table 3 reports the results of an exploratory factor analysis on the remaining four types of undeclared work. This reveals high positive loads on all four variables, with loadings ranging between 0.76 and 0.87 . Since these loadings represent coefficients of correlation between the latent construct and observed indicators, it is apparent that this single extracted factor has a substantially positive influence on attitudes towards undeclared work in general. If interpreted in terms of unique variances, which are given in the last column of Table 3 , we can see that the underlying factor explains more than 75 per cent of the variability among respondents when it comes to their attitudes towards undeclared work by a firm for another firm and a firm for a private household, while in the case of two other noncompliant behaviours this effect is slightly weaker. The result is that Bulgarian citizens apply two different standards when making judgements about undeclared work. Bulgarians have a different more permissive attitude towards individuals carrying out undeclared work for households, while not differentiating between the other types of noncompliant undeclared behaviour (i.e. attitudes towards them are determined by one latent factor). Here, therefore, we differentiate between undeclared work by an individual for a private household and undeclared work in general.

To evaluate whether institutional asymmetry (as measured by the acceptability of non-compliance regarding these two types of undeclared work) is associated with participation in the undeclared economy, we include the two following variables to measure this:

- Participation in the undeclared economy - a dummy variable with recorded value 1 for persons who answered "yes" to the question, "Have you yourself carried out any undeclared paid activities in the last 12 months?" and with recorded value 0 otherwise.

Table 2 Inter-item correlations and Cronbach's alpha

\begin{tabular}{lccc}
\hline & $\begin{array}{c}\text { Item-rest } \\
\text { correlation }\end{array}$ & $\begin{array}{c}\text { Average inter-item } \\
\text { correlation when } \\
\text { the variable is excluded }\end{array}$ & $\begin{array}{c}\text { Cronbach's alpha } \\
\text { when variable is } \\
\text { excluded }\end{array}$ \\
\hline Undeclared work by individual for private household & 0.57 & 0.70 & 0.90 \\
Undeclared work by firm for private household & 0.80 & 0.58 & 0.85 \\
Undeclared work by firm for firm & 0.77 & 0.60 & 0.85 \\
Firm hires a worker on undeclared basis & 0.75 & 0.61 & 0.86 \\
Someone partially or completely conceals their income & 0.76 & 0.60 & 0.86 \\
Test scale & & 0.62 & 0.89 \\
\hline
\end{tabular}

Source: Authors' calculations based on the Special Eurobarometer 402/Wave EB79.2

Table 3 Exploratory factor analysis - factor loadings and uniqueness

\begin{tabular}{lcc}
\hline & Factor loadings & Uniqueness \\
\hline Undeclared work by firm for private household & 0.87 & 0.24 \\
Undeclared work by firm for firm & 0.88 & 0.23 \\
Firm hires a worker on undeclared basis & 0.79 & 0.37 \\
Someone partially or completely conceals their income & 0.76 & 0.43 \\
\hline
\end{tabular}

Source: Authors' calculations based on the Special Eurobarometer 402/Wave EB79.2 
- Purchasing goods and services in the undeclared economy - a dummy variable denoting whether a respondent had purchased goods and/or services from the undeclared market during 12 months preceding the survey: 0-no, 1-yes.

Drawing upon past studies that measure attitudes towards undeclared work conducted in other countries, which reveal how the acceptability of participation in undeclared work varies by gender, age, marital status, occupation, social class, income level and area (Alm and Torgler 2006, Cannari and D'Alessio 200,7 Daude and Melguizo 2010, Daude et al. 2013, Kastlunger et al, 2013, Lago-Peñas and Lago-Peñas 2010, Martinez-Vazquez and Torgler 2009, Williams and Martinez 2014a,b), the explanatory variables here selected for investigation are:

- Gender - dummy variable for gender: 0-men, 1-women.

- Age - respondent's age, six categories: 15-24, 25$34,35-44,45-54,55-64$ and 65 or more.

- Marital status - a categorical variable describing respondent's marital status: 1-married, 2-cohabiting, 3-single, 4-separated/divorced, 5-widowed.

- Occupation - a categorical variable denoting current job status of a respondent: 1-self-employed, 2-managers, 3-other white collars, 4-manual workers, 5-house persons, 6-unemployed, 7-pensioners, 8-students.

- Social class - a categorical variable for respondent's position in society (self-assessment): 1-working class, 2-middle class, 3-higher class.

- Financial problems - a categorical variable measuring how often a respondent have problems in paying their bills: 1-most of the time, 2-from time to time, 3-almost never/never.

- Community size - a categorical variable describing the size of the area where a respondent lives: 1-rural area or village, 2-small/middle town, 3-large town.

- Bulgarian region - a categorical variable indicating a region of residence: 1- Northwest, 2- North Central, 3- Northeast, 4- Southeast, 5- Southwest, 6- South Central

To analyse the results, the two outcome variables from the exploratory factor analysis (i.e., the acceptability of an individual working undeclared for a household and the acceptability of general undeclared work) are used as dependent variables in a regression model with a range of above described socio-demographic, socio-economic and spatial explanatory variables in order to test firstly, the institutional asymmetry hypothesis and secondly, to reveal the socio-demographic, socio-economic and spatial variables strongly associated with lower adherence to the formal institutions, in order to display potential population groups where there is high institutional asymmetry. To do this, we use Tobit modelling, which accounts for the fact that the distribution of attitudes is truncated normal (Tobin 1958). In addition, given the low ratio of non-corner observations (i.e. individuals who did not express a 'null-tolerance' attitude) to the independent variables, stepwise approach is used as the most convenient method for finding significant covariates.

\section{FINDINGS}

The acceptability of participating in the undeclared economy across all five forms of undeclared work in Bulgaria is 2.46 (where 1 is totally unacceptable and 10 totally acceptable). This display that the formal and informal institutions are therefore not wholly aligned (i.e., the institutional asymmetry index is not 1.00). Nevertheless, and as identified above, the social acceptability of participation in the undeclared economy varies according to the type of undeclared work being considered. As Figure 1 displays, the Bulgarian population deem it more acceptable for an individual to undertake undeclared work for a household than to undertake other types of undeclared work. Indeed, the mean score for the acceptability of an individual engaging in undeclared work for a household is 3.71, whilst the for a firm hiring an undeclared worker this is $2.31,2.41$ for someone partially or completely concealing their income, 2.35 for a firm doing undeclared work for a household, and even lower (2.12) for firms doing undeclared work for another firm (i.e., the lower the score, the more unacceptable is the activity). Indeed, this differentiation in the acceptability of an individual participating in the undeclared economy for a private household, compared with other forms of undeclared work, is replicated across not only the EU15 but also the new member states of the European Union, suggesting that the distinction of this type of undeclared work from other types of undeclared work can be more widely applied. It is also noticeable that the level of social legitimacy of undeclared work is higher in Bulgaria than in the older member states of the European Union, but lower than in other new member states.

To see further the importance of differentiating individuals conducing undeclared work from private households from other types of undeclared work, Figure 2 reports the share of respondents reporting that these practices are highly acceptable (on the scale $1-10$, where 1 is highly unacceptable and 10 is highly acceptable, we take only those respondents who answered 8-10). This reveals that one in eight 
Figure 1 Acceptability of different types of undeclared work, a comparison of average scores for Bulgaria, EU15 and new member states

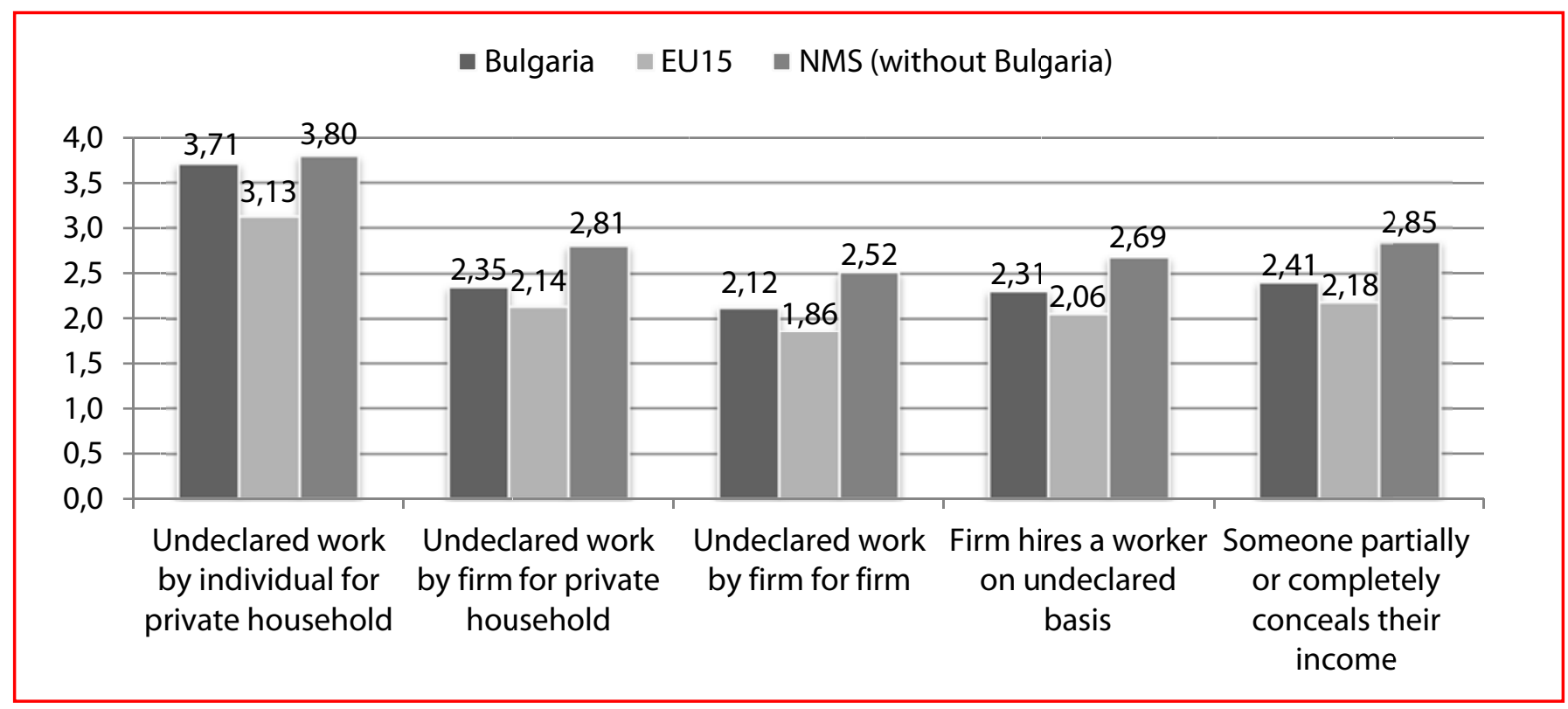

\section{Note:}

NMS - Croatia, the Czech Republic, Cyprus, Estonia, Hungary, Latvia, Lithuania, Malta, Poland, Romania, Slovenia, Slovakia EU15 - Austria, Belgium, Denmark, Germany, Greece, Finland, France, Ireland, the Netherlands,

Norway, Luxembourg, Portugal, Spain, Sweden, the United Kingdom

Source: Authors' calculations based on the Special Eurobarometer 402/Wave EB79.2

Figure 2 Share of respondents deeming undeclared work highly acceptable (8-10 where $1=$ totally unacceptable and $10=$ totally acceptable) in Bulgaria and other EU regions

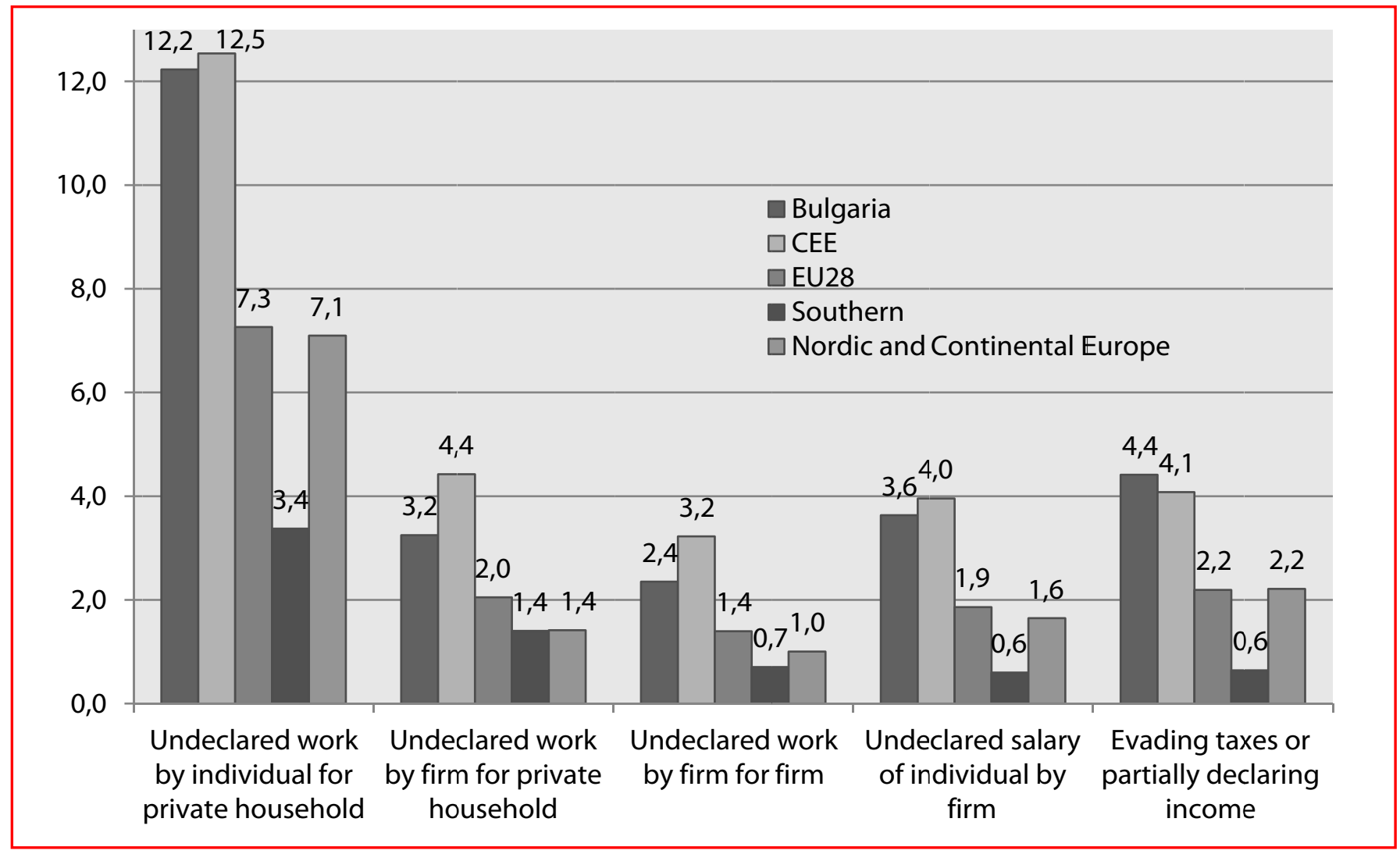

Source: Special Eurobarometer 402 on Undeclared Work in the European Union, 2014 
respondents think it is highly acceptable for an individual to undertake undeclared work for another private household but this is much lower for other types of undeclared work. This also reveals similar trends in other EU regions.
Is it the case therefore, that there is a relationship between the level of institutional asymmetry and participation in the undeclared economy? To evaluate this, Table 4 reports the results of a stepwise Tobit regression analysis for the two dependent variables,

Table 4 Tolerance of undeclared work conducted by individuals and companies, socio-economic and spatial determinants, Stepwise Tobit regression, marginal effects

\begin{tabular}{|c|c|c|}
\hline Variables & $\begin{array}{c}\text { Undeclared work by an individual for } \\
\text { a private household }\end{array}$ & $\begin{array}{c}\text { Undeclared work } \\
\text { in general }\end{array}$ \\
\hline Working undeclared & $1.492^{* * *}(0.306)$ & $0.971^{* * *}(0.281)$ \\
\hline Purchasing undeclared goods and services & $1.473^{* * *}(0.458)$ & $0.756^{* * *}(0.184)$ \\
\hline Female & - & - \\
\hline \multicolumn{3}{|l|}{ Age (RC: over 65) } \\
\hline $15-24$ & $0.291(0.473)$ & $0.474(0.282)$ \\
\hline $25-34$ & $1.076^{* *}(0.418)$ & $0.651 *(0.269)$ \\
\hline $35-44$ & $0.929 *(0.371)$ & $0.650^{* *}(0.230)$ \\
\hline $45-54$ & $0.396(0.383)$ & $0.485^{*}(0.237)$ \\
\hline $55-64$ & $0.420(0.396)$ & $0.130(0.240)$ \\
\hline \multicolumn{3}{|l|}{ Marital status (RC: married) } \\
\hline Cohabiting & - & - \\
\hline Single & - & - \\
\hline Separated/divorced & - & - \\
\hline Widowed & - & - \\
\hline \multicolumn{3}{|l|}{ Occupation (RC: Retired) } \\
\hline Self-employed & - & - \\
\hline Managers & - & - \\
\hline Other white collars & - & - \\
\hline Manual workers & - & - \\
\hline House persons & - & - \\
\hline Unemployed & - & - \\
\hline Students & - & - \\
\hline \multicolumn{3}{|l|}{ Social class (RC: Working class) } \\
\hline Middle class & - & $-0.351^{*}(0.142)$ \\
\hline Higher class & - & $0.635(0.471)$ \\
\hline \multicolumn{3}{|l|}{ Financial problems (RC: almost never/never) } \\
\hline Most of the time & - & $0.548^{* *}(0.208)$ \\
\hline From time to time & - & $0.206(0.162)$ \\
\hline \multicolumn{3}{|l|}{ Community size (RC: Rural area or village) } \\
\hline Small/middle town & - & - \\
\hline Large town & - & - \\
\hline \multicolumn{3}{|l|}{ Region (RC: Southwest) } \\
\hline Northwest & - & $-0.499 *(0.210)$ \\
\hline North Central & - & $0.053(0.231)$ \\
\hline Northeast & - & $-0.340(0.253)$ \\
\hline Southeast & - & $-0.396(0.230)$ \\
\hline South Central & - & $-0.313(0.213)$ \\
\hline Sigma & 3.829 & 2.390 \\
\hline Log likelihood & -1528.195 & -1245.535 \\
\hline LR & 83.44 & 69.30 \\
\hline Prob > LR & 0.000 & 0.000 \\
\hline Pseudo R2 & 0.020 & 0.033 \\
\hline Censored observations & 266 & 320 \\
\hline Uncensored observations & 496 & 462 \\
\hline
\end{tabular}

Significance: ${ }^{*} \mathrm{p}<0.05,{ }^{* *} \mathrm{p}<0.01,{ }^{* * *} \mathrm{p}<0.001$, (standard errors in parentheses)

Notes: 1) Both dependent variables are measured on the scale from 1 to 10 (with value 1 indicating completely unacceptable and 10 absolutely acceptable). Therefore, positive values of coefficients indicate greater tolerance

2) Models are based on forward stepwise selection method. Missing coefficients (-) indicate that no significant variation is found across a covariate

Source: Authors' calculation based on the Special Eurobarometer 402/Wave EB79.2 
namely the acceptability of individuals participating in undeclared work for private households and the acceptability of undeclared work in general. The first row in Table 4 displays that adherence to the formal rules remains strongly associated with participation in undeclared work across both dependent variables, even when controlling for other socio-demographic, socioeconomic and spatial characteristics. Since is it reasonable to assume reverse causality (i.e. that lower tax morale implies a higher propensity for participation in undeclared economy), this indicates a risk of a vicious circle in which widespread undeclared practices deteriorate tax morale, which in turn additionally increases noncompliance. The institutional asymmetry thesis is therefore positively confirmed. The greater is the nonalignment of informal institutions with formal institutions, the higher is participation in undeclared work.

This stepwise Tobit regression analysis also identifies the socio-demographic, socio-economic and spatial groups that are significantly more likely to not adhere to the formal rules when other characteristics are taken into account and held constant. The findings show that younger people in Bulgaria tend to tolerate undeclared work conducted by individuals for private households to a greater extent than older members of society. No significant variations are found across other dimensions such as gender, marital status, social class, occupation, financial problems being faced, community size and region. Turning to undeclared work more generally however, not only do middleaged people tolerate such work to a greater extent than the retired, but so too do the working class more than the middle class, and those with financial problems in paying the household bills, whilst those in the Northwest are less accepting of undeclared work than those in the Southwest.

\section{DISCUSSION}

This article has evaluated the view that undeclared work is a violation of the social contract between the state and its citizens, and arises when the norms, values and beliefs of citizens (civic morality) do not align with the codified laws and regulations of a society's formal institutions (state morality). To evaluate this, data from a survey of Bulgaria in 2013 has been used. This positively confirms the thesis; the greater is the asymmetry between formal and informal institutions, the greater is the likelihood of participation in the undeclared economy, and vice versa. This is strongly significant when holding constant other socio-demographic, socio-economic and spatial variables. This Bulgarian survey thus confirms that the undeclared economy arises when there is a lack of adherence to the formal rules.

This has direct implications for how the undeclared economy is tackled. According to institutional theory, institutional asymmetry can be tackled using either disincentives (sticks) to dissuade citizens from engaging in socially legitimate but illegal activities, or incentives (carrots) to facilitate participation in legal activities (Matthias et al. 2014, North 1990). Conventionally, the Bulgarian government when tackling the undeclared economy, mirroring other South-East European governments, has used disincentives. They have sought to make the cost of being caught and punished greater than the pay-off from participating in the undeclared economy (Allingham and Sandmo 1972, Dekker et al. 2010). Firstly, penalties and sanctions have been increased and/or secondly, the likelihood of detection improved such as by increasing workplace inspections and by improving data sharing and matching to identify individuals engaged in undeclared employment (e.g., CSD 2009b, 2011, Dzhekova et al. 2014). In the period 2005 to 2009 for example, a review of measures to combat undeclared work in Bulgaria reveals that of the 222 measures, the majority were focused on deterrence, using stricter requirements, tougher sanctions and improved detection (CSD 2009b). Indeed, amendments to the Labour Code enacted in 2006 and 2008 merely extended the powers of control and introduced harsher penalties and fines (Loukanova and Bezlov 2007, Daskalova 2013a). The problem with using this disincentives approach, however, is that tougher sanctions and improving detection decreases voluntary compliance because it undermines respect for the fairness of the system and leads to greater rather than less undeclared work (Chang and Lai 2004, Murphy 2005, Murphy and Harris 2007).

If participation in the undeclared economy is to be tackled therefore, a rather different policy approach will be required. Two options exist. Firstly, incentives to behave legitimately can be used, such as direct and indirect tax incentives to either suppliers or consumers of undeclared work to encourage them to operate in the formal economy. An example is the food voucher system whereby employers can provide employees with food vouchers up to BGN $60(€ 30)$ per month and this is nether included in the employees' taxable income and is treated as a social expense and exempt from all taxes for employers (KC2 and Industry Watch, 2010). In 2013, the scheme was used by 4,0005,000 employers and covered 350,000 employees, or around 15-16 per cent of all employed (Dzhekova and Williams 2014). In a 2010 evaluation of the scheme by the consultancy companies Industry Watch and KC2 
Ltd (2010), the finding was that employers use food vouchers to substitute for undeclared wage payments, thus leading to a reduction in the under-reporting of salaries.

The problem nevertheless, is that such incentives are in effect bribes offered precisely because they would not otherwise comply with the codified laws and regulations (i.e., state morality). Far more effective and cost-efficient than continuously offering bribes to conform, is to align informal institutions with formal institutions. Here, therefore, a second and rather different policy approach is proposed that seeks to reduce the gap between civic morality and state morality.

On the one hand, this requires policy measures to align civic morality with state morality, including education and awareness raising campaigns regarding the importance and benefits of paying taxes. An example is the 'Coming into the Light' awareness raising campaign of the Bulgarian Industrial Capital Association (Williams 2014a). Other possibilities are to use 'your taxes are paying for this' signs in hospitals, schools, on ambulances and other public construction projects. These education and awareness raising campaigns, moreover, and as Table 4 reveals, could be usefully targeted at middle-aged people who view themselves as working class.

On the other hand, alterations in formal institutions are also needed. Drawing upon a large body of management research at the organisational level where a shift has taken place from 'hard' to 'soft' HRM, and from bureaucratic to post-bureaucratic management (Legge 1995, Thompson and Alvesson 2005, Watson 2003), a similar shift could be applied at the societal level when tackling participation in undeclared work. This would result in a policy shift away from the conventional low commitment, low trust and adversarial 'hard' policy approach seeking compliance through tight rules, close supervision and monitoring, prescribed procedures and centralised structures. Instead, and mirroring how desirable behaviour change is elicited at the organisational level, a high trust, high commitment 'soft' policy approach would be pursued to nurture self-regulation through internalised commitment. This necessitates a shift away from the current 'cops and robbers' approach that views citizens as criminals and towards a customer service-oriented approach which views them as clients. To do this, improvements in the procedural and redistributive justice and fairness of formal institutions are necessary so that citizens believe that the authorities are treating them in a respectful, impartial and responsible manner, believe that they pay their fair share and believe that they receive the goods and services they deserve (Molero and Pujol 2012, Murphy 2005).

\section{CONCLUSIONS}

This article has propounded an explanation for the undeclared economy which asserts that the greater is the asymmetry between formal and informal institutions (i.e., citizens' civic morality and state morality), the greater is the likelihood of participation in the undeclared economy, and vice versa. The outcome is that tackling the undeclared economy requires a focus upon reducing this lack of alignment of formal and informal institutions. This is a different policy approach to that currently adopted.

However, this paper has limitations. The major one is that even if the quantitative analysis reveals the importance of aligning formal and informal institutions, it has not identified the reasons for the lack of adherence to the formal rules by the Bulgarian population. Future qualitative research is therefore necessary to pinpoint these reasons. This will then enable targeted policy measures to be developed to attack these causes of the lack of alignment of formal and informal institutions.

In this article, in conclusion, a way of explaining and tackling the undeclared economy has been outlined. Whether this is also valid in South-Eastern Europe more generally, as well as other global regions, now requires evaluation. If this article therefore stimulates such evaluations, one of its major intentions will have been achieved. If it also encourages governments in South-East Europe to recognise this institutional asymmetry explanation for the undeclared economy and to begin exploring policies to reduce this asymmetry, rather than persisting with the detection and punishment, then this article will have achieved its fuller intention.

\section{REFERENCES}

Allingham, M. G. and Sandmo, A. 1972. Income tax evasion: a theoretical analysis. Journal of Public Economics 1(2): 323-338.

Andrews, D., Caldera Sanchez, A. and Johansson, A. 2011. Towards a Better Understanding of the Informal Economy. Paris: OECD Economics Department Working Paper no. 873, OECD.

Baric, M. and Williams, C. C. 2013. Tackling the undeclared economy in Croatia. South-Eastern Europe Journal of Economics 1: 7-36.

Baumol, W.J. and Blinder, A. 2008. Macroeconomics: principles and policy. Cincinnati, $\mathrm{OH}$ : South-Western Publishing.

BICA. 2011а. Доклад за основните предизвикателства за диагностика, ограничаване и превенция на неформалната икономика [Report on the key 
challenges to the diagnosis, restriction and prevention of the informal economy]. Sofia: BICA

BICA. 2011b. Неформалната икономика и работодателите [The informal economy and the employers]. Sofia: BICA

BICA. 2012. Комплексен аналитичен доклад за състоянието на неформалната икономика в България и изводи за нейното ограничаване и превенция [Complex analytical report on the state of the informal economy in Bulgaria and conclusions on its reduction and prevention]. Sofia: BICA.

Bogdanov, L. and Stanchev, K. 2010. Сивата икономика в България: състояние към средата-края на 2010 г. [The grey economy in Bulgaria: situation as of 2010]. Sofia: Institute for Market Economics.

Castells, M. and Portes, A. 1989. World underneath: the origins, dynamics and effects of the informal economy. In The Informal Economy: studies in advanced and less developing countries, edited by A. Portes, M. Castells and L. Benton, 1-19. Baltimore: John Hopkins University Press.

Chang, J.J. and Lai, C.C. 2004. Collaborative tax evasion and social norms: why deterrence does not work. Oxford Economic Papers 56(2): 344-368.

Chavdarova, T. 2014. Envelope wages. Paper presented at the States and States of Informality Conference, Sofia, 5 September.

Center for the Study of Democracy. 2009a. Crime without Punishment. Countering Corruption and Organised Crime in Bulgaria. Sofia: CSD.

Center for the Study of Democracy. 2009b. Policies to Counter the Effects of the Economic Crisis: Hidden Economy Dynamics 2009. Policy Brief No. 20. Sofia: CSD.

Center for the Study of Democracy. 2011. The Hidden Economy in Bulgaria and the Global Economic Crisis. Sofia: CSD.

Center for the Study of Democracy. 2012. Bulgarian Serious and Organised Crime Threat Assessment 2010-2011. Sofia: CSD.

Center for the Study of Democracy. 2013a. The Hidden Economy in Bulgaria, Policy Brief No. 37. Sofia: CSD.

Daskalova, N. 2013a. Joint effective control on undeclared work, Bulgaria. Eurofound [Online]. Available: http:// www.eurofound.europa.eu/areas/labourmarket/tackling/cases/bg017.htm (accessed 21 December 2014).

Dau, L.A. and Cuervo-Cazurra, A. 2014. To formalize or not to formalize: entrepreneurship and pro-market institutions. Journal of Business Venturing 29: 668-686.

Daude, C., Gutiérrez, H. and Melguizo, A. 2013. What drives tax morale? a focus on emerging economies. Review of Public Economics 207: 9-40

De Soto, H. 1989. The Other Path: the economic answer to terrorism. London: Harper and Row.
De Soto, H. 2001. The Mystery of Capital: why capitalism triumphs in the West and fails everywhere else. London: Black Swan.

Dekker, H., Oranje, E., Renooy, P., Rosing, F. and Williams, C.C. 2010. Joining up the fight against undeclared work in Europe. Brussels: Commission of the European Communities, Employment, Social Affairs and Equal Opportunities DG.

Denzau, A.T. and North, D. 1994. Shared mental models: ideologies and institutions. Kyklos 47: 3-30.

Dolenec, D. 2013. Democratic Institutions and Authoritarian Rule in Southeast Europe. Colchester: ECPR Press.

Dzhekova, R., Franic, J., Mishkov, L. and Williams, C.C. 2014. Tackling the Undeclared Economy in FYR Macedonia. A Baseline Assessment. GREY Working Paper No. 3. Sheffield: Sheffield University Management School.

Dzhekova, R. and Williams, C.C. 2014. Tackling the Undeclared Economy in Bulgaria. A Baseline Assessment. GREY Working Paper No. 1. Sheffield: Sheffield University Management School.

Elgin, C. and Öztunali, O. 2012. Shadow Economies around the World: Model Based Estimates. Istanbul: Bogazici University.

European Commission. 2007. Special Eurobarometer 284. Undeclared Work in the European Union. Brussels: European Commission

European Commission. 2012. Report from the Commission to the European Parliament and the Council. On Progress in Bulgaria under the Cooperation and Verification Mechanism. COM(2012) 411 final. Brussels: European Commission.

Franic, J. and Williams, C.C. 2014. The Undeclared Economy in Croatia. A Baseline Assessment. GREY Working Paper No. 2. Sheffield: Sheffield University Management School.

Frey, B.S. and Torgler, B. 2007. Tax morale and conditional cooperation. Journal of Comparative Economics 35: 136-159.

Gallin, D. 2001. Propositions on trade unions and informal employment in time of globalisation. Antipode 19: 531-49.

Gasparaeniene, L., Kartasova, J. and Remeikiene, R. 2014. Evaluation of shadow economy emergence and development factors in service sector: Greek case. Academic Journal of Interdisciplinary Studies 3: 139- 145.

Geertz, C. 1963. Old Societies and New States: the quest for modernity in Asia and Africa. Glencoe IL: Free Press.

General Labour Inspectorate. 2013. Activity Report 2012. General Labour Inspectorate [Online]. Available: http:// www.gli.government.bg/upload/docs/2013-06/SKMBT_ DOKLAD_IA_GIT_2012.pdf (Accessed 4 April 2014).

Gërxhani, K. 2004a. The informal sector in developed and less developed countries: a literature survey. Public Choice 120: 267-300. 
Gërxhani, K. 2004b. Tax evasion in transition: outcome of an institutional clash? Testing Feige's conjecture in Albania. European Economic Review 48(7): 729-45.

Goev, V. 2009. Estimating the Hidden Economy in Bulgaria. South-East Europe Review for Labour and Social Affairs 12(1): 77-93.

Helmke, G. and Levitsky, S. 2004. Informal institutions and comparative politics: a research agenda. Perspectives on Politics 2: 725-740.

Hudson, J, Williams, C. C., Orviska, M. and Nadin, S. 2012. Evaluating the impact of the informal economy on businesses in South East Europe: some lessons from the 2009 World Bank Enterprise Survey. The South-East European Journal of Economics and Business 7: 99-110.

ILO. 2013. Women and Men in the Informal Economy: statistical picture, available at http://laborsta.ilo.org/informal_ economy_E.html (last accessed 18 November 2014)

ILO. 2014. Transitioning from the informal to the formal economy. Report V (1), International Labour Conference, 103rd Session (2014). Geneva: ILO.

KC2 Ltd. and Industry Watch Group. 2010. Food Voucher Issuance in Bulgaria: Economic and Fiscal Impact. Sofia: KC2.

Legge, K. 1995. Human Resource Management: rhetorics and realities. Basingstoke: Macmillan.

Lewis, A. 1959. The Theory of Economic Growth. London: Allen and Unwin.

Loukanova, P. and Bezlov, T. 2007. Undeclared Work from SYSDEM Correspondent. Bulgaria. European Employment Observatory [Online]. Available: http://www.euemployment-observatory.net/resources/reviews/ NationalArticles/BulgariaUDW2007.pdf (Accessed 31 October 2014).

Maloney, W.F.2004. Informality Revisited. World Development 32: 1159-1178.

Mathias, B. D., Lux, S., Crook, T. R., Autry, C. and Zaretzki, R. 2014. Competing against the unknown: the impact of enabling and constraining institutions on the informal economy. Journal of Business Ethics, http://dx.doi. org/10.1007/s10551-013-2030-6.

Meagher, K. 2010. Identity Economics: social networks and the informal economy in Nigeria. New York: James Currey.

Ministry of Finance. 2010. The grey economy: approaches for measuring and modelling. Brief methodological analyses. Sofia: Ministry of Finance.

Molero, J. C. and Pujol, F. 2012. Walking inside the potential tax evader's mind: tax morale does matter. Journal of Business Ethics 105: 151-162.

Murphy, K. and Harris, N. 2007. Shaming, shame and recidivism: a test of re-integrative shaming theory in the white-collar crime context. British Journal of Criminology 47: 900-917.
Murphy, K. 2005. Regulating more effectively: the relationship between procedural justice, legitimacy and tax non-compliance. Journal of Law and Society 32: 562-589.

Murphy, R. 2012. Closing the European Tax Gap: a report for Group of the Progressive Alliance of Socialists and Democrats in the European Parliament. Downham Market: Tax Research LLP.

Nenovsky, N. and Hristov, K. 1999. A Study of the Money in Transaction after Establishing the Currency Board in Bulgaria. Bulgarian National Bank Working Paper. Sofia: Bulgarian National Bank.

North, D. C. 1990. Institutions, Institutional Change and Economic Performance. Cambridge: Cambridge University Press.

Nwabuzor, A. 2005. Corruption and development: new initiatives in economic openness and strengthened rule of law. Journal of Business Ethics 59: 121-138.

OECD. 2012. Reducing Opportunities for Tax Non-Compliance in the Underground Economy. Paris: OECD.

Perachi, F., Perotti, V. and Scarpetta, S. 2007. Informality and Social Protection: Preliminary Results from Pilot Surveys in Bulgaria and Colombia. World Bank Social Protection Discussion Paper No. 0717. Washington D.C.: World Bank Group.

Perotti, V. and Sanchez Puerta, M. 2009. Personal Opinions about the Social Security System and Informal Employment: Evidence from Bulgaria. World Bank Social Protection Discussion Paper No. 0915. Washington D.C.: World Bank Group.

Podrug, N. 2011. Influence of national culture on decisionmaking style. South East European Journal of Economics and Business 6(1): 37-44.

Remeikiene, R., Gasparaeniene, L. and Kartasova, J. 2014. Country-level determinants of the shadow economy during 2005-2013: the case of Greece. Mediterranean Journal of Social Sciences 5: 454-460.

Ristovska, M., Mojsoska-Blazevski, N. and Nikolov, M. 2012. An alternative view to the tax evasion: the effect of tax morale on paying taxes in Macedonia and EU countries. Serbian Journal of Management 8: 169-183.

Round, J., Williams, C. C. and Rodgers, P. 2008. Corruption in the post-Soviet workplace: the experiences of recent graduates in contemporary Ukraine. Work, Employment and Society 22: 149-166

Schneider, F. and Williams, C. C. 2013. The Shadow Economy. London: Institute of Economic Affairs.

Schneider, F. 2013. Size and development of the shadow economy of 31 European and 5 other OECD countries from 2003 to 2013: a further decline. Retrieved from http://www.econ.jku.at/members/Schneider/files/publications/2013/ShadEcEurope31_Jan2013.pdf (accessed 6 November 2014). 
Siqueira, A. C. O., Webb, J. and Bruton, G. D. 2014. Informal entrepreneurship and industry conditions. Entrepreneurship Theory and Practice, DOI: 10.1111/etap. 12115

Slavnic, Z. 2010. Political economy of informalisation. European Societies 12: 3-23.

Stanchev, K. 2005. Ed. Study of Incentives, Characteristics and Strategies of Firms Operating in the Shadows'. Sofia: Institute for Market Economics.

Thompson, P. and Alvesson, M. 2005. Bureaucracy at work: misunderstandings and mixed blessings. In The Values of Bureaucracy, edited by P. du Gay, 121-140. Oxford: Oxford University Press.

Tobin, J. 1958. Estimation of relationships for limited dependent variables. Econometrica 26: 24-36.

Torgler, B. 2004. Tax morale in Asian countries. Journal of Asian Economics 15(2): 237-266.

Watson, T.J. 2003. Sociology, Work and Industry. London: Routledge.

Webb, J. W., Tihanyi, L., Ireland, R. D. and Sirmon, D. G. 2009. You say illegal, I say legitimate: entrepreneurship in the informal economy. Academy of Management Review 34: 492-510.

Williams, C. C. 2012. Cross-national variations in the underreporting of wages in South-East Europe: a result of overregulation or under-regulation? The South East European Journal of Economics and Business 7(1): 53-61.
Williams, C. C. 2013. Evaluating cross-national variations in the extent and nature of informal employment in the European Union. Industrial Relations Journal 44: 479-494.

Williams, C. C. 2014a. Confronting the Shadow Economy: evaluating tax compliance and behaviour policies. Cheltenham: Edward Elgar.

Williams, C. C. 2014b. Out of the shadows: a classification of economies by the size and character of their informal sector. Work, Employment and Society 28: 735-753.

Williams, C. C. and Martinez, A. 2014a. Explaining cross-national variations in tax morality in the European Union: an exploratory analysis. Studies in Transition States and Societies 6: 5-17.

Williams, C. C. and Martinez, A. 2014b. Why do consumers purchase goods and services in the informal economy? Journal of Business Research 67: 802-806.

Williams, C. C., Nadin, S., Kedir, A. and Vorley, T. 2013. Evaluating the extent and nature of the informalisation of employment relations in South-East Europe. European Journal of Industrial Relations 19: 91-107.

Williams, N. and Vorley, T. 2014. Institutional asymmetry: how formal and informal institutions affect entrepreneurship in Bulgaria. International Small Business Journal doi: 10.1177/0266242614534280

World Economic Forum. 2014. Global Competitiveness Report. Available at: http://www.weforum.org/reports/ global-competitiveness-report-2013-2014 